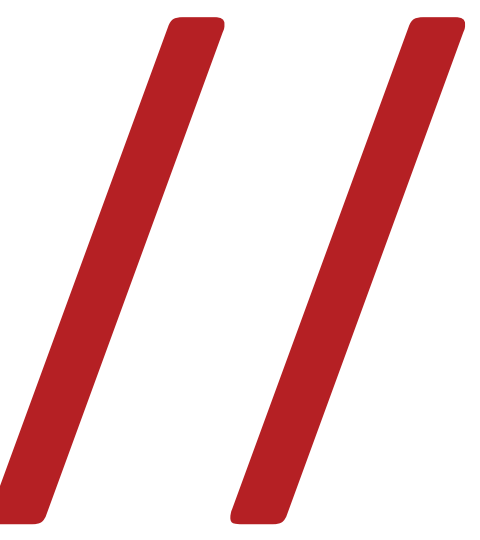

\title{
Considerações sobre os números musicais das chanchadas
} Considerations on the musical numbers of Brazilian chanchadas

\section{Flávia Cesarino Costa ${ }^{1}$}

\footnotetext{
${ }^{1}$ Professora de Teoria e História do Audiovisual da Universidade Federal de São Carlos (UFSCar). É autora de O primeiro cinema: espetáculo, narração, domesticação (Azougue, 2005). Pertence ao Cinemídia - Grupo de Estudos sobre História e Teoria das Mídias Audiovisuais, na UFSCar, e é pesquisadora do Intermidia Project - Towards an Intermedial History of Brazilian Cinema: Exploring Intermediality as a Historiographic Method (https://research.reading. ac.uk/intermidia/) financiado por AHRC/Reino Unido e Fapesp/Brasil. E-mail: flavia.cesarino@uol.com.br
} 
Resumo: comentam-se as abordagens de Irina Rajewsky e Agnes Pethö sobre a intermidialidade no cinema e no audiovisual e, em seguida, discutem-se as possibilidades de sua aplicação como categoria crítica na análise de alguns números musicais de filmes do diretor Watson Macedo nos anos 1950. Pesquisadores conectam os números musicais de chanchadas brasileiras ao teatro de revista, ao rádio, à indústria fonográfica e ao cinema de Hollywood, mas as relações entre essas diferentes mídias têm sido entendidas tendo o filme como principal foco explicador. Esses números musicais podem ser analisados diferentemente dentro do circuito mais amplo de mídias e práticas culturais urbanas, tal como propõe Charles Musser.

Palavras-chave: cinema brasileiro; chanchada; intermidialidade; números musicais; carnaval.

Abstract: this article comments on accounts by Irina Rajewski and Agnes Pethö on the intermediality in cinema and audiovisual production and discusses the use of intermediality as a critical category on the analysis of musical numbers of Brazilian chanchadas of the 1950s directed by Watson Macedo in the 1950s. Film researchers have worked on the connections between Brazilian chanchadas and popular theatre, radio, phonographic industry and Hollywood. The relationship between these distinct cultural practices have been discussed considering the film as the main point of discussion, but, according to Charles Musser, these musical numbers may be better understood inside the broader circuit of media and urban cultural practices.

Keywords: Brazilian cinema; chanchada; intermediality; musical numbers; carnaval. 
O presente artigo busca abordar a intermidialidade como método historiográfico para o estudo de números musicais das chanchadas brasileiras. Serão discutidas abordagens teóricas sobre a intermidialidade e o cinema que nos parecem produtivas, a saber, as conceituações de Irina Rajewski (2012) e Agnes Pethö (2011). Em seguida, faremos considerações metodológicas sobre o uso desses conceitos na pesquisa dos números musicais, bem como a crítica de algumas concepções históricas sobre as chanchadas, por meio da análise de exemplos retirados de duas comédias do diretor Watson Macedo.

Este artigo é resultado parcial de investigação realizada no âmbito do Projeto Intermídia - Para uma história intermidiática do cinema brasileiro: explorando a intermidialidade como um método historiográfico, pesquisa colaborativa entre a Universidade de Reading (Reino Unido) e a Universidade Federal de São Carlos, que se dedica a estudar o cinema em geral e o cinema brasileiro, em particular, sob a perspectiva da intermidialidade, explorando as articulações com outras manifestações artísticas e práticas culturais - tais como o teatro e os demais espetáculos de palco: música, artes plásticas, rádio². Meu objetivo aqui é discutir aspectos do uso da intermidialidade como método historiográfico aplicado a práticas culturais específicas associadas aos números musicais das chanchadas. Trata-se de pesquisa em andamento, da qual o presente artigo é um dos resultados. Não pretendo, nesse sentido, estabelecer uma ampla descrição da história de práticas correlatas, tais como o teatro de revista ou o rádio. $\mathrm{O}$ assunto central não é o número musical em geral ou como unidade básica de reflexão associada às suas conexões com a trama dos filmes, mas sim aquilo que, nesses números musicais, reporta às relações intermidiáticas no cinema brasileiro dos anos 1950. O presente artigo dá continuidade a reflexões iniciadas em artigo anterior denominado "Chanchada e intermidialidade", no qual trabalhei com números musicais do filme Aviso aos Navegantes (1950), de Watson Macedo (COSTA, 2016).

\footnotetext{
${ }^{2} \mathrm{O}$ Projeto IntermIdia - Towards an Intermedial History of Brazilian Cinema: Exploring Intermediality as a Historiographic Method (https://research.reading.ac.uk/intermidia/) é uma pesquisa colaborativa de âmbito internacional realizada entre 2015 e 2018, financiada com recursos do convênio entre Arts \& Humanities Research Council (AHRC) e a Fundação de Amparo à Pesquisa do Estado de São Paulo (Fapesp) e desenvolvida por professores da Universidade de Reading (Reino Unido) liderados pela Prof. ${ }^{a}$ Dr. ${ }^{a}$ Lúcia Nagib, e professores do Departamento de Artes e Comunicação da Universidade Federal de São Carlos (Brasil) vinculados ao grupo de pesquisa Cinemídia (<https://cinemidiaufscar. wordpress.com/apresentacao/> e <http://dgp.cnpq.br/dgp/espelhogrupo/3112598408988006>), ao qual pertenço: Prof. ${ }^{a}$ Dr. ${ }^{a}$ Luciana Sá Leitão Corrêa de Araújo, Prof. Dr. Samuel José Holanda de Paiva e Prof. ${ }^{a}$ Dr. ${ }^{a}$ Suzana Reck Miranda, bem como pela Dr. ${ }^{a}$ Margarida Maria Adamatti, pesquisadora de pósdoutorado associada ao projeto. Agradeço a estes pesquisadores a frutífera interlocução, e à Fapesp pelos recursos que possibilitam esta pesquisa (Processo n²014/5082l-3).
} 
O objetivo da pesquisa mais ampla na qual este trabalho se insere é pesquisar nos números musicais dos filmes a atuação de produtoras cinematográficas e seus profissionais, e o circuito dos músicos pelas rádios e espaços de exibição, bem como a indústria fonográfica na qual transitavam músicas e artistas. Neste artigo, entretanto, optei por trabalhar com alguns exemplos retirados de filmes de Watson Macedo, por ser ele um diretor de chanchadas menos pesquisado do que José Carlos Burle e Carlos Manga, e por ver em seus números musicais exemplos de um esforço de encenação específico, que respondia ao cinema americano e ao mesmo tempo às referências brasileiras, revelando conexões intermidiáticas com atividades culturais sincrônicas aos seus filmes. O que se entende aqui como intermidialidade tem a ver com o que Agnes Pethö (2011) chama de "experiência sensorial" e que acontece naquilo que Rick Altman (1992) conceitua como “o filme como evento". É a partir das inscrições ou rastros dessa experiência sensorial nos números musicais que pretendo abordar as conexões com formas específicas de produção e encenação 3 .

Interessa-me desconectar a discussão da relação entre trilhas sonoras e números musicais e suas narrativas da discussão dos números musicais como entidades com uma dinâmica diferenciada. A referência aqui é, como detalharei, a ideia de Charles Musser (2004), que considera a importância explicativa da inter-relação das práticas de cena (teatro e cinema) e de exibição de várias formas de entretenimento, em contextos específicos nos quais o cinema se insere como apenas uma atividade entre outras.

\section{Intermidialidade}

O uso do termo "intermidialidade" generalizou-se a partir dos anos 1990 em diferentes tipos de abordagens que procuravam dar conta de fenômenos que aconteciam "entre" as mídias. Em seu artigo "Intermidialidade, intertextualidade, 'remediação': uma perspectiva literária sobre a intermidialidade”, publicado originalmente em 2005, Irina Rajewski explica que o adjetivo “intermidiático" passou a designar "aquelas configurações que têm a ver com um cruzamento de fronteiras entre as mídias e que, por isso, podem ser diferenciadas dos fenômenos intramidiáticos assim como dos fenômenos transmidiáticos (por exemplo, o aparecimento de certo motivo, estética ou discurso em uma variedade de mídias diferentes)”. No entanto,

\footnotetext{
${ }^{3}$ Por fazer "considerações", o presente artigo não se pretende exaustivo e panorâmico. A intenção é partir de exemplos privilegiados para avançar possíveis comentários. Nesse sentido, não se trata de definir um corpus prévio mais específico, ainda que o interesse esteja nos filmes de Watson Macedo, e a proposta é partir de questões e caminhar para exemplos. Esclareço nesse sentido que a pesquisa está sendo feita não a partir de um grupo fechado de periódicos pesquisados, que seriam rastreados em todos os seus números, mas sim a partir de um período (1949-1953) e suas conexões e circularidades.
} 
o termo "intermidialidade" não coincide com nenhuma teoria unificada e assiste diferentes concepções sobre a natureza das fronteiras entre as mídias, o que requer que se defina, segundo a autora, em cada estudo qual a concepção particular de intermidialidade do autor (2012, p. 18).

Em seu artigo, Rajewski (2012, p. 19) observa que as concepções de intermidialidade dividem-se entre abordagens históricas de tipo sincrônico (que desenvolvem tipologias das formas de intermidialidade) e abordagens históricas diacrônicas (que desenvolvem tipologias de histórias intermidiáticas das mídias). Nossa pesquisa alinha-se à perspectiva diacrônica, ainda que detenhamos nosso olhar num tempo específico: a década de 1950.

Em seguida Rajewsky distingue, de um lado, a intermidialidade entendida como "condição ou categoria fundamental" da intermidialidade e, de outro, a intermidialidade entendida como "uma categoria crítica para a análise concreta de produtos ou configurações de mídias individuais e específicas" (2012, p. 19). Como nosso objetivo é trabalhar com números musicais singulares, permanecemos nessa segunda categoria.

No entanto, a mais importante distinção feita por Rajewski é a das três diferentes categorias de intermidialidade, a saber "transposição midiática", “combinação de mídias" e "referências intermidiáticas". A "transposição midiática" é aquela encontrada em adaptações de um produto de mídia para outra mídia, na qual se transferem personagens, situações, narrativas, como um livro que é adaptado ao cinema ou ao teatro. A “combinação de mídias” abrange pelo menos duas mídias entendidas como diferentes e que se articulam, cada uma na sua própria materialidade, na composição de um mesmo produto: são exemplo a ópera, peças de teatro, filmes, performances e instalações.

A terceira categoria é, no entanto, a que nos parece mais apropriada para a análise fílmica: a "referência intermidiática”. É a evocação de técnicas de outra mídia, mas o produto "usa seus próprios meios para se referir a uma obra individual específica produzida em outra mídia [...], seja para se referir a um subsistema midiático específico (como por exemplo um determinado gênero de filme), ou a outra mídia como sistema” (RAJEWSKI, 2012, p. 25).

As "referências intermidiáticas" só podem gerar uma ilusão de práticas específicas de outra mídia, mas tal ilusão provoca no receptor sensações específicas de outras mídias. Como método historiográfico, a intermidialidade torna claros não apenas os subsistemas em jogo (tais como o musical hollywoodiano, as performances no rádio ou as encenações das revistas), mas também a relação entre mídias nos produtos que se acreditam específicos da mídia cinema. Assim, entendo que buscar 
na mídia "filme" os contextos e referências intermidiáticas de outras mídias é usar a intermidialidade como método historiográfico.

Em seu livro Cinema and intermediality (2011), Agnes Pethö entende a experiência do filme como uma vivência ambígua em que convivem a imersão dos sentidos na obra e ao mesmo tempo a quebra do fluxo, quando surge um componente reflexivo. Para a autora, as técnicas de intermidialidade seriam as que quebram a transparência da imagem fílmica e efetuam transgressões, não apenas nos óbvios casos de visível estilização, mas também dentro do cinema de representação realista. A intermidialidade aparece, portanto, quando o filme aponta ao mesmo tempo para o mundo real e para sua própria midialidade. A lógica poética da intermidialidade no cinema é localizada por Pethö no mecanismo pelo qual uma mídia aparece como se fosse outra. Assim, a intermidialidade pode ser entendida como a repetição ou a reinscrição de uma mídia como forma na forma de outra mídia, onde o próprio procedimento de intermidialidade é figurado, quer dizer, torna-se observável e se refere, reflexivamente, a si mesmo. No caso das chanchadas, os números musicais aparecem como momentos privilegiados em que, seja intencionalmente, seja por problemas de produção, a reinscrição de estratégias de outras mídias torna-se visível. Feitas essas considerações teóricas, passaremos à conceituação e aos comentários sobre as chanchadas e seus números musicais.

\section{Palcos e telas nas comédias brasileiras: os números musicais}

Numerosos estudos sobre as comédias musicais no cinema brasileiro indicam a clara influência de práticas culturais como o rádio e o teatro de revista, bem como da cultura carnavalesca, sobre os filmes produzidos entre as décadas de 1930 e 1950 (AUGUSTO, 1989; DENNISON; SHAW, 2004; LENHARO, 1995; SCHVARZMAN, 2008; SHAW, 2000, 2003; VIEIRA, 1977, 1983, 1984, 1987, 1996, 2012). Em suas diferentes análises, esses pesquisadores conectam as chanchadas brasileiras da primeira metade do século XX ao teatro de revista, ao rádio, à indústria fonográfica e ao cinema de Hollywood, mas as relações entre essas diferentes mídias tendem a ser entendidas tendo o filme como principal foco explicador. O presente artigo pretende discutir a metodologia de análise deste período do cinema brasileiro, pelo exame da influência da indústria do entretenimento na configuração dos números musicais dessas chanchadas, tal como vêm fazendo pesquisas mais recentes (ARAÚJO, 2015; CIOCCI, 2010; FREIRE, 2011, 2013; HEFFNER ${ }^{4}$, 2012). Nosso

\footnotetext{
${ }^{4}$ Considerar também o que Hernani Heffner declara para Sandra Ciocci em entrevista transcrita em sua dissertação de mestrado (CIOCCI, 2010, p. 186-215).
} 
objetivo é contribuir para essas análises, mas afastando-nos do cinema para voltar a ele com um olhar mais amplo e de um ponto de vista externo. Propomos uma abordagem intermidiática que desloque das explicações a centralidade do cinema e insira na discussão a complexidade de outras mídias, tendo como referência a história agregada de palcos e telas tal como proposta por Charles Musser (2004).

Neste artigo pretendemos formular algumas perguntas sobre as implicações dos números musicais para uma história intermidiática e formular questões relativas ao que Rick Altman chama, na sua introdução ao livro Sound theory, sound practice (1992, p. 2-4) de "filme como evento", em oposição ao que seria o "filme como texto". Considerado por décadas como texto pela história do cinema, o filme foi entendido por muito tempo como uma entidade fechada, à qual eram aplicadas variadas formas de análise fílmica que não consideravam as diferenças de público, gênero, classe, etnia ou formas de exibição. O modelo do "filme como evento", por outro lado, considera como variáveis fundamentais as condições de exibição, as variações de performance, a multiplicidade de receptores, as diferentes versões, a materialidade dos eventos nos quais os filmes acontecem, as acústicas, a herança performática do cinema, as encenações ao vivo que precediam os filmes, as decorações das salas. Consideramos que os números musicais das chanchadas eram momentos nos quais a materialidade musical da exibição aparecia, e o público participava, cantando os sucessos musicais.

Os números musicais são parte importante das comédias musicais no Brasil, cuja existência estende-se da introdução do som em 1931 até a chegada da TV no final dos anos 1950. Na verdade, filmes cantantes já eram uma prática antes disso, quando músicas eram interpretadas durante a exibição de filmes silenciosos. Mas, com a generalização dos programas de rádio nos anos 1940, cantores, músicos e arranjadores que participavam de programas ao vivo passam a aparecer nas trilhas musicais dos filmes, assim como atores e comediantes do teatro de revista. O vínculo entre o cinema e outras formas de entretenimento popular levou à consolidação do mais popular gênero de cinema brasileiro, a chanchada. Entre os anos 1930 e 1950, esse termo designava pejorativamente os filmes que se configuravam como comédias compostas por uma mistura de números musicais e situações cômicas, mais ligadas ao carnaval do que propriamente conectadas a uma narração consistente (VIEIRA, 2012, p. 141-142). Entretanto, como explica Rafael de Luna Freire, o termo "chanchada" aparece nos anos 1940 como um adjetivo a indicar um ambiente de insatisfação dos críticos com essa produção cinematográfica brasileira, mas passará por um "processo de 
substantivação" até ser utilizado nos anos 1970 de forma mais objetiva, como sinônimo de um gênero de comédias especificamente brasileiro (FREIRE, 2011, p. 103).

João Luiz Vieira vem há muito ressaltando a importância da cultura carnavalesca para o entendimento dessas comédias musicais e suas irregularidades, cuja vitalidade sintonizava o disco, o rádio, a revista teatral e a chanchada com as práticas culturais cotidianas do carioca (VIEIRA, 1977, 1983, 1987, 1996, 2012). Os números musicais das chanchadas cristalizam um emaranhado de conexões entre esses filmes e seu contexto e, nesse sentido, interessam-nos como objeto de pesquisa justamente por sua narratividade instável, pela musicalidade que transborda, pela carnavalização que irrompe e pela clara interferência da lógica de outras mídias em sua encenação para a câmera.

A partir dos anos 1940, o cinema de Hollywood foi substituindo o desnível entre as performances musicais e os enredos por narrativas mais integradas, que se tornaram um padrão. Mas nas chanchadas brasileiras a transformação, nas décadas de 1940 e 1950, na direção de tramas coerentes não eliminou certa separação entre enredo e números musicais, o que serviu de argumento para que muitos dos nossos críticos as considerassem ruins.

Em seu livro sobre o musical de Hollywood, Jane Feuer comenta que a aura de leveza dos musicais americanos, em que cantores e dançarinos se relacionavam com objetos e ambientes cotidianos - como nos filmes de Fred Astaire e Gene Kelly -, era conseguida, na verdade, por um pesado conhecimento tecnológico. Diz ela que “a engenharia, como modo de produção do musical de Hollywood, é disfarçada por um conteúdo que se apoia pesadamente numa bricolagem. Assim, nós esquecemos todo o cálculo subjacente ao número musical, que ganha uma aura de espontaneidade absoluta" (FEUER, 1993, p. 7, tradução minha). Nos números musicais brasileiros desse período, entretanto, acontecia o oposto: a "engenharia” da encenação ficava completamente à mostra. De sorte que, nas chanchadas, as conexões com outras mídias estavam sempre aparecendo, e ficavam evidentes os processos de produção: não eram como os filmes americanos, em que tudo parecia muito natural. Tratava-se, portanto, de outra lógica. A escolha dos cantores e a forma de encenação das performances musicais estavam ligadas ao funcionamento mais amplo que configurou a cultura de massa brasileira até o final dos anos 1950 e que é assim descrito por Alcir Lenharo em seu livro Cantores do Rádio:

Depois do fechamento dos cassinos o implemento do teatro de revista e das chanchadas cinematográficas formam com o rádio 
um tripé básico da produção massiva de cultura, mas o rádio sempre manteve um papel mais abrangente e concentrador. Ao redor desse tripé gravitavam a indústria do disco, as editoras de músicas, as revistas especializadas, a publicidade. A vida musical do Rio e das capitais tinha nesse tripé o ponto de referência de suas atividades. Cantores, compositores, músicos, artistas de teatro, rádio atores, de uma forma ou de outra, transitavam por um desses espaços culturais. (LENHARO, 1995, p. 135)

Se, como nos lembra Lenharo, a centralidade do rádio orientava a cultura de massa no Brasil dos anos 1940 e 1950, as chanchadas articulavam-se claramente a essa engrenagem por seus numerosos números musicais, que compunham parte substancial de cada um desses filmes. Esses números musicais estão ligados umbilicalmente às várias práticas extracinematográficas de encenação ligadas à indústria fonográfica, à aparição dos cantores nas rádios e no star system da imprensa e ao carnaval como fato cultural intensamente coberto pelas mídias.

A presença do cantor de rádio era essencial para dar à mistura de música e humor das chanchadas um apelo popular. Se essas comédias pareciam precárias em sua formatação, elas eram, por outro lado, altamente rentáveis e valiam-se apenas do mercado interno para manter-se e lucrar. Para os músicos convidados a atuar em seus filmes, a Atlântida, maior produtora de chanchadas, - fundada em 1941 e comprada em 1947 pelo maior exibidor do Rio de Janeiro, Luis Severiano Ribeiro - não tinha essa imagem de improvisação criada pelos críticos da época, que, segundo Lenharo, "não percebiam a originalidade do fenômeno e insistiam em reduzir a Atlântida a uma cópia subdesenvolvida do cinema americano" (1995, p. 116).

Na década de 1950, as revistas teatrais atingem o ápice e a decadência. Os sambas e marchas convivem com a presença crescente dos ritmos nordestinos e depois com a chegada do rock, do jazz e da bossa nova. O rádio inicia a década com a força dos programas de auditório e termina com o impulso cada vez maior da televisão. E os cantores se movem gradualmente dos auditórios das rádios para palcos menores e para os estúdios das gravadoras. Nos números musicais dos filmes, o trânsito entre mídias vai condicionar os elementos e estratégias da figuração cinematográfica. São momentos privilegiados para o pesquisador, nos quais o contexto mais amplo se manifesta na forma específica. Inseridos nas tramas, essas performances reverberam referências que vão das práticas culturais locais ao padrão hollywoodiano de encenação. Há uma circulação de atores, sucessos musicais e rotinas entre os filmes, o que torna razoável pensar numa espécie de diálogo entre os produtos midiáticos de um mesmo ano ou temporada. 


\title{
Primeira questão: práticas de encenação
}

Entremos nessas chanchadas através de seus números musicais. Alguns exibem cantores do rádio secundados por orquestras ou conjuntos musicais repetindo na diegese situações de apresentações musicais com a orquestra ao fundo. Muitos incorporam a aparição de grupos de sambistas e de cabrochas ou de bailarinos e coristas do teatro. Outros prescindem da presença de orquestras e músicos diegéticos, porque mais conectados às tramas, e incorporam as atuações de personagens de diferentes tipos, conforme as origens dos atores: esquetes com experimentados atores de revistas, canções interpretadas por atores ou cantores atuando como personagens cantores. As diversas formas de encenação dos números musicais das chanchadas indicam uma primeira questão de método a enfrentar: como distinguir, em cada caso, a sobreposição ou a presença de diferentes tipos de práticas de palco?

É necessário entender e explicar as músicas e os participantes no seu momento. Quem são esses cantores no panorama musical da época? Se algumas músicas são destinadas ao carnaval, qual o seu papel dentro do filme e fora dele, no trânsito dos sucessos do rádio? Como as músicas são promovidas pela imprensa ilustrada? Que artistas são veiculados pelo star system local? De que circuito de produções teatrais muitas delas bem mais rentáveis que os filmes - vemos atores de revista que participam dessas performances nas chanchadas? Como esses números musicais apontam para o trânsito de signos próprio de seu contexto? Alcir Lenharo lembra que

\begin{abstract}
o começo dos anos 1950 era um período de especial criatividade musical no calendário momesco. Haroldo Lobo, Braguinha, Nássara, Wilson Batista, Klécius Caldas e Armando Cavalcanti, Zé da Zilda, entre outros, estavam sempre na ponta. Predominavam as marchinhas, mas o frevo aparecia bastante. (LENHARO, 1995, p. 200)
\end{abstract}

Aviso aos Navegantes, filme dirigido por Watson Macedo para a Atlântida em 1950, tem a maior parte de seu tempo preenchido por dezesseis números musicais. Tomemos para análise a apoteose musical do filme, que celebra a chegada dos personagens ao Brasil com a música Rio de Janeiro, de Ari Barroso, cantada por Francisco Carlos no teatro diegético que se supõe existir dentro do navio. O cantor despontava para o sucesso desde o lançamento da canção Meu brotinho, interpretada por ele no ano anterior em Carnaval no Fogo (1949) e gravada em disco vários meses após o filme - só depois de ser aceito pelo público (CIOCCI, 2010, p. 94), quando Francisco Carlos passou a ser assunto obrigatório nas revistas ilustradas. 
Temos nesse número musical (Figura 1) um cenário com o Pão de Açúcar, similar aos que aparecem nos filmes de Hollywood e também nas revistas teatrais. No fotograma, temos ao fundo o próprio cantor cercado por dançarinos e, em primeiro plano, dois personagens da trama, encarnados pela atriz Eliana Macedo (que se fez dentro do cinema) e o ator cômico Oscarito (um astro do teatro de revista). Vemos claramente os elementos do tripé da cultura de massa dos anos 1940-50, mencionado por Alcir Lenharo: um cantor de rádio que não dança nem atua muito bem, a estrela de cinema que dança e canta (no cinema, mas não no rádio), e o cômico de teatro de revista que faz tudo o que a cena pede, já que esta forma teatral exigia do ator múltiplas capacidades cênicas - cada um deles atua em sua especialidade. A referência visual de Macedo é o cinema, mas nela são introduzidos elementos de outras origens. Ele, sabiamente, insere o cantor de rádio que tem performance pouco dinâmica, numa cena cinemática, mas ele permanece no fundo, para que sejam destacadas as atuações de Oscarito e Eliana. Há dentro do número musical, portanto, a presença de diferentes atuações, diferentes registros ficcionais (a trama e o espetáculo), e os temas e ambientação do carnaval que dá o tom da encenação.

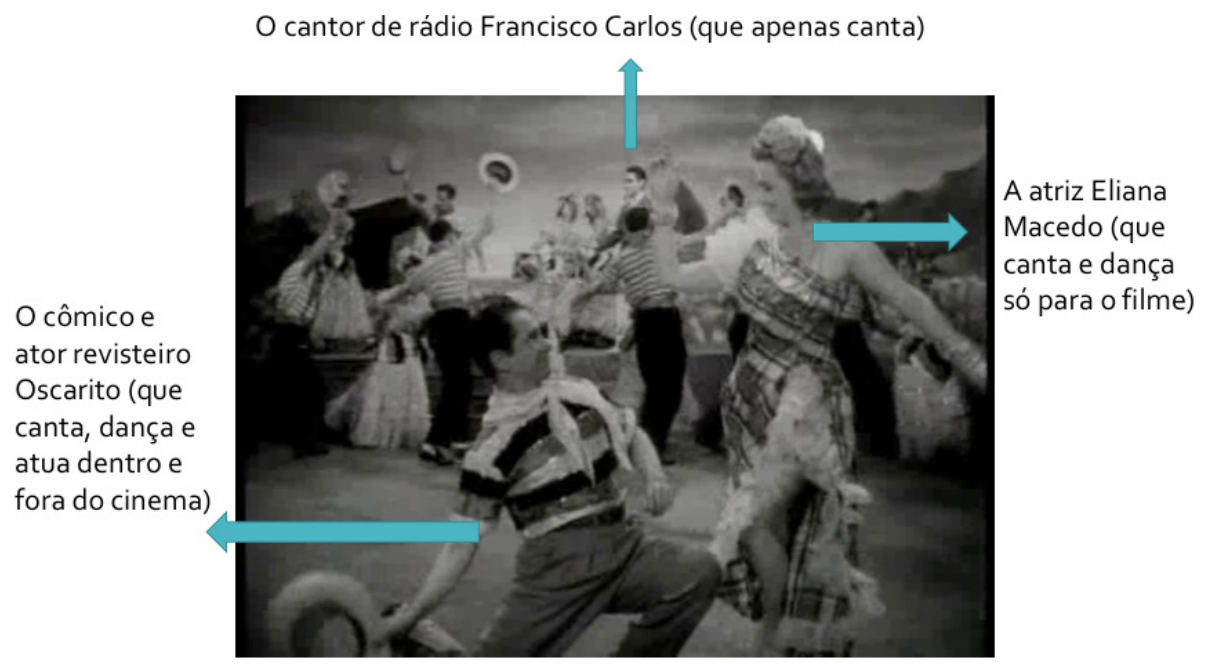

Figura 1: O cantor Francisco Carlos, a atriz de cinema Eliana Macedo e o ator do teatro de revista Oscarito na apoteose "Rio de Janeiro", em Aviso aos navegantes (1950), de Watson Macedo.

Fonte: Aviso aos navegantes (1950); textos elaborados pela autora.

Como muitas das atrações do rádio, Francisco Carlos foi escolhido por sua persona de cantor bem-apessoado que enlouquecia as fãs. Uma matéria de A cena 
muda de 7 de junho de 1951, páginas 10-11 (Figura 2), comenta a participação dele em Carnaval no Fogo, filme anterior de Watson Macedo filmado em 1949:

O sucesso foi tanto e tamanho o interesse despertado pelo público e pela crítica que o próprio José Carlos Burle lhe ofereceu um papel principal num dos próximos filmes da Atlântida. Francisco Carlos rejeitou a proposta, pois não desejava seguir a carreira de ator, aceitando, apenas, quando tivesse ocasião, de figurar em quadros musicais. Tanto assim que tomou parte em mais duas películas daquela empresa: Não é nada disso e Aviso aos Navegantes. (FRANKIE, 1951, p. 10-11)

Ou seja, não lhe interessava ser mais do que um cantor. Como explica Alcir Lenharo, cantar nos filmes era, para os cantores do rádio, "uma experiência agradável, quase sempre realizada num momento de preparação intensa do carnaval”. A experiência lhes agradava e "cantar nos filmes era importante para as carreiras deles, como era importante fazer parte do elenco de uma gravadora, ser contratado pela Rádio Nacional, ser requisitado para excursões - sinais de sucesso" (LENHARO, 1995, p. 115).

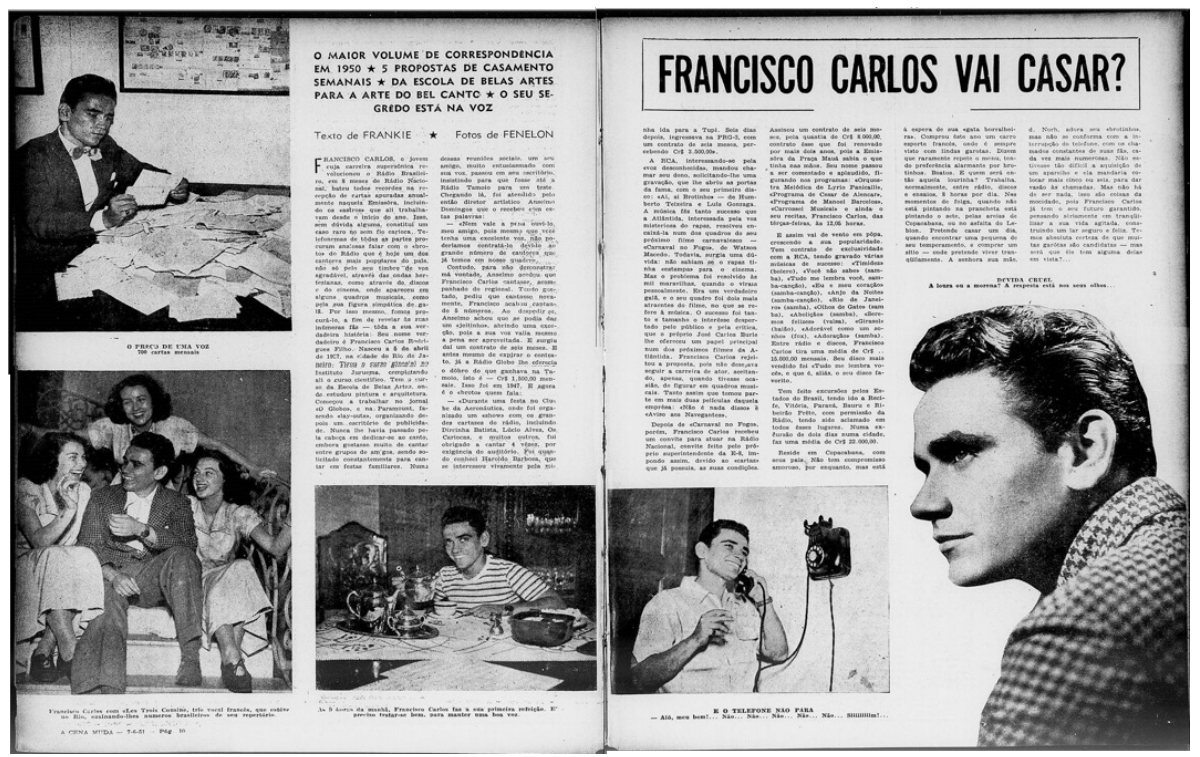

Figura 2: A cena muda de 7 de junho de 1951, páginas 10-11 (FRANKIE, 1951). Fonte: Hemeroteca Digital Brasileira, Biblioteca Nacional.

Para esses artistas, a imagem da Atlântida era a de uma empresa bemsucedida e, por isso, ainda que não pudessem atuar bem, o efeito multiplicador 
desses números filmados era o que lhes interessava. A maior parte dos cantores no cinema só participava dos números musicais. Tais artistas raramente se firmavam como atores. Da mesma forma, vedetes de revista, como Virgínia Lane, ou atrizes do cinema, como Eliana Macedo, que cantavam bem não fizeram carreira de cantoras. Adelaide Chiozzo era sanfoneira e acabou fazendo papéis de melhor amiga da mocinha em vários filmes, mas nunca foi uma boa atriz. Quando Ivon Curi ou Bené Nunes atuavam, faltava a naturalidade dos atores. Mas precisava? A presença dos artistas certamente interessava aos diretores dos filmes como atrativo importante para o público e era largamente noticiada no rádio e na imprensa. A escolha das atrações musicais das chanchadas foi sempre sustentada na popularidade e na rentabilidade de outras formas de arte como a música popular e o rádio, e os enredos se adaptavam a isso. E por isso nos filmes brasileiros do período é visível essa circulação de aptidões. Há cantores que cantam, músicos que conseguem atuar, revisteiros que fazem tudo, atrizes que também cantam, rumbeiras que dançam e tentam atuar, atores que nem tentam cantar. E, como lembra Sandra Ciocci, nenhum galã brasileiro cantava no cinema (CIOCCI, 2010). Isso era característico do star system específico das chanchadas e comédias musicais, uma vez que, diferentemente dos Estados Unidos, o rádio e o mercado fonográfico constituíam uma indústria muito mais poderosa e atuante do que o cinema. Essa indústria pautava a mídia impressa e a programação das estações de rádio. Números musicais com cantores de rádio que atuavam de forma estática ou contida exibiam a face visual de artistas de imenso sucesso nos programas de auditório e revisteiros comentados repetidamente pelas revistas ilustradas.

A escolha de cantores e artistas que figuravam nas chanchadas bem como os detalhes de suas performances poderiam ser visualmente precários ou estáticos, mas resultavam de um diálogo entre os produtores e diretores dos filmes e as preferências do mercado musical. O que levanta um primeiro desafio de método: seria possível analisar esses números relacionando-os às tramas, sem considerar suas influências externas? Parece-nos que não. Pois, para a maioria dos artistas e contrariamente ao desejo de uma historiografia centrada nos filmes, o cinema era um ganha pão adicional. Como explica João Luiz Vieira, citado por Stephanie Dennison e Lisa Shaw, a renda das estrelas das chanchadas não vinha de seus salários no cinema, mas sim de suas apresentações ao vivo em circos e teatros pelo país, algumas vezes abrindo as temporadas dos filmes (VIEIRA, 1984, p. 67 apud DENNISON; SHAW, 2004, p. 63).

De fato, muitos atores, cantores, arranjadores, músicos, cenógrafos e figurinistas que trabalharam nas chanchadas vinham do rádio e das revistas, mas eles 
continuavam a sobreviver dessas atividades. Seria, portanto, necessário dimensionar a importância real desses filmes na carreira, no salário, no cotidiano dos vários profissionais envolvidos, que em sua maioria não tinham o cinema como atividade principal. É significativo que Oscarito, um dos maiores atores de chanchadas, tenha dito, em entrevista ao Museu da Imagem e do Som do Rio de Janeiro citada por Sérgio Augusto: "O que eu ganhava no cinema só dava para me sustentar. Dinheiro, mesmo, eu ganhei com os espetáculos que dava pelo interior” (AUGUSTO, 1989, p. 94). Alguns historiadores sugerem que esses artistas vêm do circo e do teatro, num movimento numa só direção, porque eles estão preocupados com os filmes. No entanto, essa ideia pode ser empobrecedora se deixarmos de lado que havia uma interação multidirecional entre essas diferentes atividades. Nesse sentido, é preciso diminuir a importância do cinema para poder explicá-lo, inserindo seu funcionamento na lógica de um circuito cultural mais amplo. Dessa primeira questão resulta um desafio. Se há no número musical práticas de encenação de diferentes origens, como repensar as chanchadas incluindo esses elementos externos?

\section{Segunda questão: erudito e popular}

Em seu livro De pernas para o ar, Neyde Veneziano explica que o processo de abrasileiramento do teatro de revista já durante a Primeira Guerra vai resultar na criação de um gênero, a revista carnavalesca, em que o rei momo vira um compère que lança as marchinhas do carnaval. Nesse processo, o enredo se enfraquece, a ligação com a música popular se torna "estreita e indissolúvel", e a importância da música se equipara ao texto, diferentemente do modelo português ou francês. O teatro de revista será o maior divulgador da música popular brasileira até o surgimento do rádio nos anos 1920, e "personagens de várias etnias aparecem para lançar as danças da moda: mulatas, portugueses, italianos, malandros, caipiras” (VENEZIANO, 2006, p. 126). Há, portanto, estreita relação entre a criticada dissociação dos números musicais em relação à trama dos filmes e uma tradição teatral baseada na preeminência da música popular sobre os enredos.

Ao pesquisar a cultura de massa carioca nos anos 1920, Tiago de Melo Gomes (2004) mostra que as críticas ao teatro de revista lamentavam a falta de conexão entre as cenas, o uso de tipos que se repetiam, o abuso dos sambas e, pior de tudo, o grande sucesso disso tudo em meio ao público. São ressalvas bem parecidas às que se fariam, depois, às chanchadas. Para Gomes, são "críticas, ancoradas no contraste entre essa forma mais popular de teatro e as formas canônicas" mais respeitáveis (GOMES, 2004, p. 126). Ela traz à tona uma importante característica herdada pelas chanchadas: a 
naturalidade com que se mistura aspectos da cultura erudita ou de elite e a irreverência da cultura popular, principalmente nos números musicais. Mais do que interrupções às tramas, os momentos musicais eram frequentemente uma oportunidade para os diretores de chanchadas misturarem as referências culturais da época, conversando com o cinema de Hollywood e com a cultura popular.

Nas décadas de 1940 e 1950, o teatro de revista carioca terá grande influência do empresário Walter Pinto (Figura 3), que, com sua mistura de bailarinos clássicos, coristas, modelos nus, atores, cantores e vedetes, vai embalar a mistura de erudito e popular em espetáculos feéricos. Vedetes, efeitos visuais e cenários aspiravam visualmente à sofisticação das Ziegfeld Follies reprocessadas nos espetáculos da Broadway, mas essas populares e rentáveis produções encenavam ao mesmo tempo os textos cheios de safadezas e duplos sentidos tradicionais do teatro de revista. Espetáculos cheios de mulheres bonitas e com pouca roupa, nas quais a música, o carnaval, os efeitos visuais e apoteóticos em rampas e plataformas conquistavam o público, processavam a influência do cinema americano e faziam também sua mistura de erudito e popular.

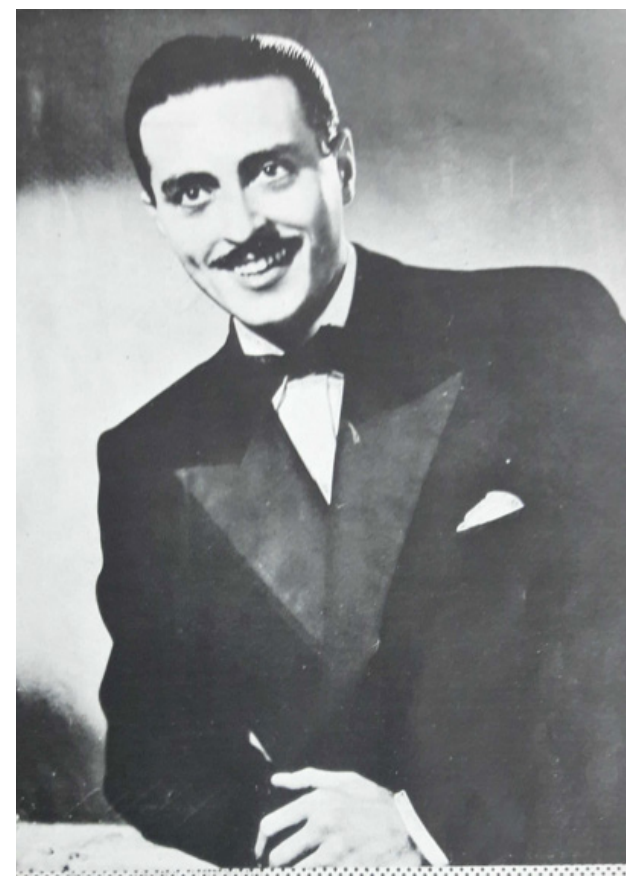

Figura 3: Walter Pinto (1913-1994), empresário teatral e dono do Teatro Recreio. Fonte: Acervo Walter Pinto, Cedoc/Funarte. 
Uma importante figura nas revistas e filmes musicais nesse período é a bailarina Juliana Yanakiewa, búlgara nascida na Áustria que veio ao Brasil nos anos 1940 e não pôde mais voltar por causa da guerra. Em 1950 Yanakiewa fez parte do mundo do teatro de revista carioca como coreógrafa e bailarina que transitava do clássico ao popular e trabalhou tanto em filmes e no teatro de revista como em apresentações de balé clássico. Yanakiewa é um símbolo desse tipo de mistura (Figura 4).

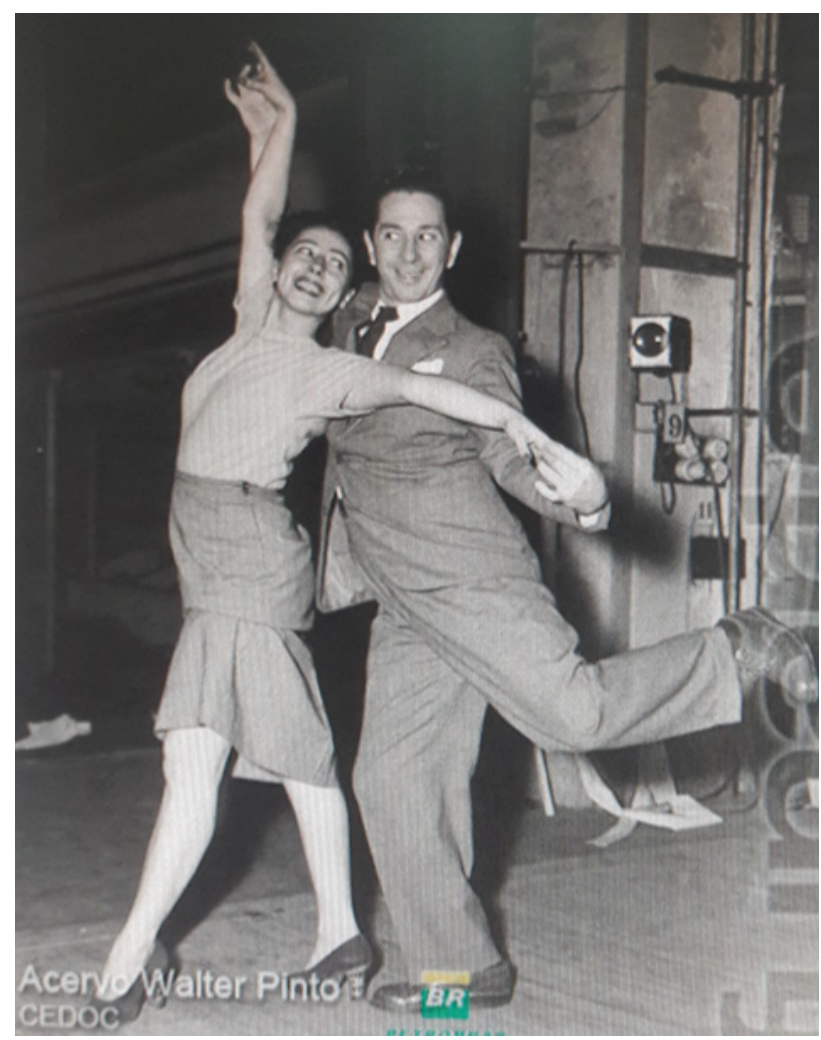

Figura 4: Juliana Yanakiewa ensaia com Oscarito para a revista Muié macho, sim sinhô (1950).

Fonte: Acervo Walter Pinto, Cedoc/Funarte.

O intercâmbio de artistas e técnicos entre as revistas e o cinema era natural, um dado explorado pelas revistas ilustradas que documentam esse entrecruzamento. Aviso aos navegantes tem muitas conexões com a revista Muié macho, sim sinhô, encenada no Teatro Recreio por Walter Pinto no mesmo ano de 1950 (Figura 5). Nessa luxuosa produção, Walter Pinto usou efeitos cênicos sofisticados, tais como chuvas de pétalas de rosa, cortinas de fumaça, vestuários inventivos e apoteoses impressionantes, que conquistaram o público. Parte do elenco do filme, como Grande Otelo e Oscarito, 
participava da revista, que tinha ainda Chocolate, Dalva de Oliveira, os bailarinos Edgardo Deporte e Marina Marcel, a vedete Virgínia Lane, show girls e a própria Yanakiewa como primeira bailarina e coreógrafa. Tocavam-se autores populares e clássicos, entre eles José Maria de Abreu, Rimsky-Korsakov e Khatchaturian. A apoteose era o baião Paraíba, de Humberto Teixeira e Luiz Gonzaga, que curiosamente não aparece no programa da peça. Foram 300 apresentações em cinco meses, simultâneas à produção do filme, que absorveu estilos, escolhas, músicas e atores da revista.
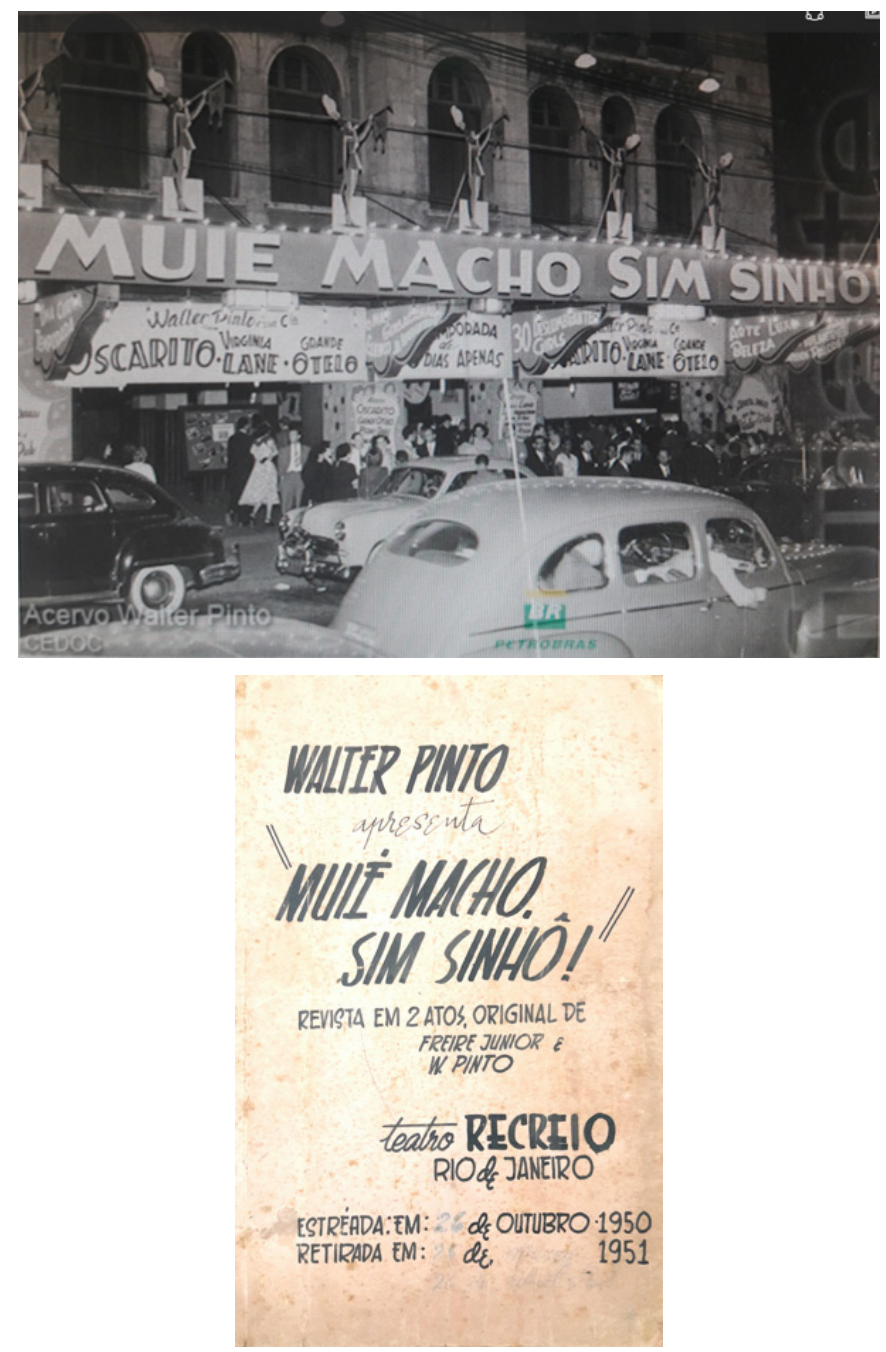

Figura 5: O Teatro Recreio, no Rio de Janeiro, onde a revista Muié macho, sim sinhô (1950) foi apresentada por cinco meses, e a capa do roteiro da peça submetido à censura. Fonte: Acervo Walter Pinto, Cedoc/Funarte. 
A revista foi promovida pela imprensa no circuito do estrelismo intermidiático. O Cruzeiro, por exemplo, exagerou um incêndio em parte do teatro para colocar fotos ensaiadas dos atores supostamente fugindo ou ajudando a apagar o fogo, em matéria de David Nasser, publicada em 2 de dezembro de 1950, denominada "O espetáculo continua", que falava do empresário e da atividade do teatro (NASSER, 1950, p.18-19). Grande Otelo é levado no colo por uma "loira", e Virgínia Lane "chora" por ter quase perdido suas joias.

Um dos números musicais do filme é o conhecido balé em que Yanakiewa dança o Concerto número 1 para piano de Tchaikovsky, tocado por Bené Nunes e sua orquestra, e que se transforma num casal que dança a música em ritmo de gafieira, num arranjo de Lindolfo Gaya ${ }^{5}$. Watson Macedo vai aqui se inspirar na mistura de baião e Rimsky-Korsakov de Muiê macho, sim sinhô, e pode também ter se inspirado na cena de Ciúme, sinal de amor (The Barkleys of Broadway, 1949, Charles Walters), lançado no ano anterior, em que o pianista Oscar Levant toca o mesmo concerto de Tchaikovsky. Se a apoteose da revista era um número musical baseado na música Paraíba, é essa mesma música que passa a ser tocada pela banda de Bené Nunes em Aviso aos navegantes, quando a mocinha resolve brigar com sua rival na pista de dança.

Comentamos este exemplo para lembrar que a mistura do erudito e do popular não é uma inovação da chanchada ou de seus diretores, mas uma prática frequente no teatro popular. Tal questão também é central nos musicais de Hollywood. Jane Feuer chama de narrativas "ópera versus suingue" àqueles musicais que colocam o conflito entre a cultura clássica e a popular no centro da trama e que sempre mostram a vitória final do estilo popular. No entanto, ainda que esse tipo de disputa apareça em muitas chanchadas, nelas a mistura de popular e erudito é menos uma questão de disputa e mais propriamente uma convivência amigável, que vem do teatro desde o século XIX.

Como aponta Sandra Ciocci em sua tese sobre a Atlântida, os compositores de trilhas, tais como Lindolfo Gaya, sofriam por transitar entre a música erudita e a música popular, sendo até rejeitados de ambos os lados. Tinham formação erudita, mas era nos programas populares das rádios que conquistaram segurança econômica. Assim, explica a autora que "toda a trilha musical dos filmes da Atlântida, musicais e não musicais, tem como base a trilha do cinema americano da década de 1930, mas os procedimentos chegam aos nossos filmes dos anos 1940 e $1950 \mathrm{com}$ um toque de popular, de brasileiro" (CIOCCI, 2010, p. 65).

${ }^{5}$ Para uma análise mais detalhada desse número musical, ver meu artigo "Chanchada e intermidialidade" (COSTA, 2016). 
A questão da convivência entre erudito e popular sugere um segundo desafio metodológico: como podemos avaliar se as escolhas de diretores e produtores são autorais ou colaborativas, considerando esse trânsito entre mídias? Como limitamos este nosso objeto? Será suficiente ou produtivo analisar o corpo de filmes de certo diretor e suas maneiras de encenar esses números musicais, ou devemos incluir um rastreamento de seu repertório de referências, inserido nas práticas culturais de seu tempo?

Sabemos, por exemplo, que Watson Macedo tendeu a ser desvalorizado por uma parte da crítica e dos historiadores por ser considerado muito "americanizado" e, ao mesmo tempo, por não aderir aos mecanismos críticos da paródia, tal como fizeram outros diretores de chanchadas. Entretanto, sua capacidade de encenar números musicais e produzir uma integração crescente entre os músicos e cantores, as rotinas de vaudeville e os enredos românticos e de suspense dos filmes está relacionada à colaboração de profissionais que circulavam nessas mídias e nos filmes de vários diretores e produtoras.

\section{Terceira questão: os números musicais ultrapassam o âmbito dos próprios filmes}

Considerar que os números musicais sofrem uma série de influências de outras práticas culturais, muitas delas mais importantes para o funcionamento da dinâmica da cultura de massa e no bolso dos artistas, leva-nos a uma terceira questão. Inseridos, com mais ou menos adequação, nos enredos que lhe servem de base, os números musicais ultrapassam claramente os limites do próprio filme e apontam para uma dinâmica horizontal de circulação de referências compartilhadas.

Inúmeros exemplos podem elucidar esta relação. Comento apenas alguns. Trata-se de dois números musicais de É fogo na roupa, chanchada dirigida por Watson Macedo em 1952, depois que o diretor saiu da Atlântida e tornou-se produtor independente. O filme é rodado no Hotel Quitandinha, onde ocorrem escaramuças entre as integrantes de um congresso de esposas e um grupo de homens que tentam sabotar a reunião. Alguns dos números musicais acontecem num palco diegético, no restaurante do Hotel, no qual são cantados os sucessos musicais do ano, trabalhados no rádio ou nas revistas. Num deles o cantor Jorge Goulart interpreta a marchinha Mulher do Diabo, de Antônio Almeida, acompanhado de orquestra. A música, lançada no rádio, fazia referência a outros dois de seus sucessos recentes - as músicas Dominó e Jezebel (esta, uma versão de Caribé da Rocha de um ritmo afro-cubano de Shanklin) - e seria sucesso no carnaval do ano seguinte, em 1953, depois de ser veiculada pelo filme, pelo rádio e pela imprensa. Em janeiro de 1953, a marcha circularia entre inúmeras músicas, no suplemento de carnaval da revista Fon-Fon, que sugeria uma fantasia para cada música do ano (Figura 6). 


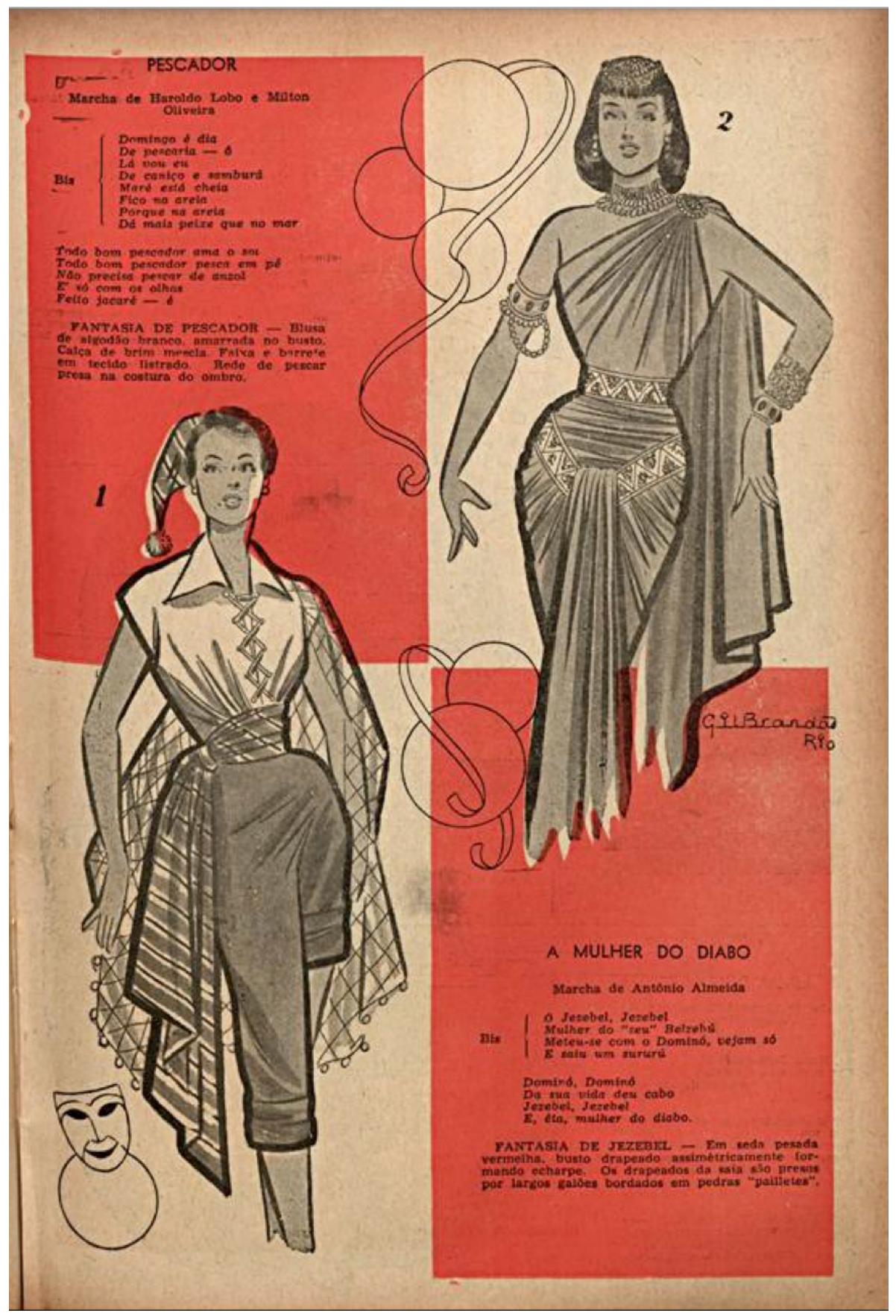

Figura 6: "A mulher do Diabo" na Fon-Fon, 24 de janeiro de 1953, com recomendação de fantasia.

Fonte: Hemeroteca Digital Brasileira, Biblioteca Nacional. 
Ao cantar Mulher do Diabo, Jorge Goulart faz sua performance mesmo sem pertencer ao grupo de personagens. Não é apresentado pelo mestre de cerimônias que aparece em outras cenas do filme. Surge como cantor famoso e dá o seu recado no palco, onde canta com sua voz projetada, diante da orquestra (Figura 7). O sucesso de Goulart já vinha desde 1949, quando cantou Balzaqueana (uma composição de Nássara e Wilson Batista) no filme Carnaval no Fogo, de Watson Macedo. Em 1950, sua interpretação da marchinha ganharia $2^{\circ}$ lugar no concurso de músicas de carnaval da prefeitura do Rio de Janeiro. Em 1950, Goulart lançou Sereia de Copacabana (também de Nássara e Batista, com execução da Orquestra Tabajara de Severino Araújo) para o carnaval, em Aviso aos navegantes, amparado pela gravadora Continental e disputado pela Rádio Tupi e Nacional. Sereia de Copacabana ficou em $3^{\circ}$ lugar no concurso de 1951. Esse é um exemplo entre inúmeros, nos quais se verifica a extensa rede de interesses subjacente à escolha dos músicos para participar desses filmes, muito mais determinante do que a necessidade de uma conexão explícita com a trama de É fogo na roupa.

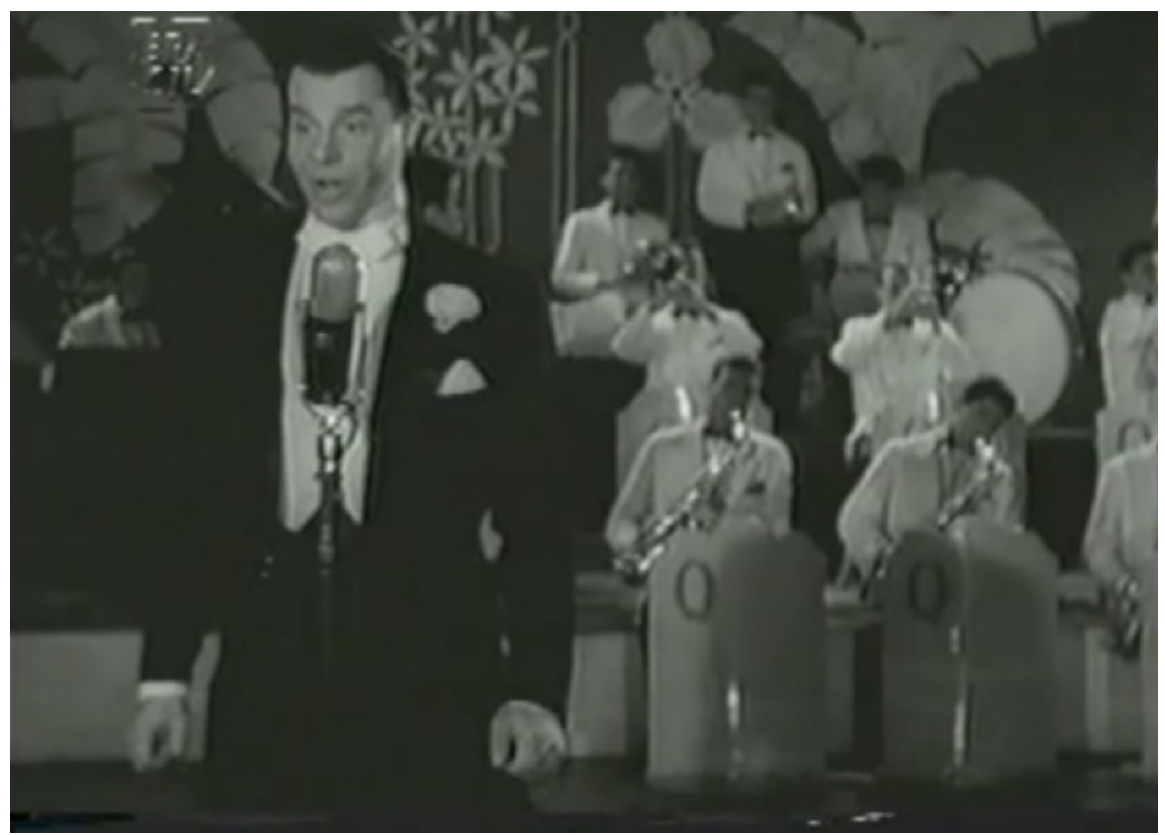

Figura 7. Jorge Goulart canta Mulher do Diabo em É fogo na roupa (1952, Watson Macedo). Fonte: Acervo Walter Pinto.

Em um número posterior, Ankito dança o universal tango La cumparsita (G. M. Rodríguez) com a chefe das esposas, encarnada por Violeta Ferraz. A dança é 
executada de forma debochada num salão cercado por mesas em que estão sentados os outros personagens. Ankito trabalhou no circo e faz no filme uma interpretação cheia de ação física e cantorias paródicas. Nesse número, os dois atores do teatro de revista fazem uma performance cômica que, ainda que motivada pela trama e inserida na diegese, é uma encenação típica daquela forma teatral. No ano seguinte, esses mesmos dois atores fariam parte do elenco da revista de Walter Pinto, É fogo na jaca (1953).

\section{Considerações finais}

Os exemplos comentados levantam importantes perguntas. Não se pretende aqui fazer uma taxonomia de características ou de artistas. O objetivo é tão somente indicar algumas questões. Se os números musicais ultrapassam o âmbito dos próprios filmes, é necessário mais do que discutir se estão bem ou mal conectados às tramas. Trata-se também de discutir com que mídias estão conversando e, assim, fazer um movimento para fora dos filmes para poder voltar a eles. Ou seja, precisamos mergulhar tanto verticalmente para dentro do filme quanto verificar como nele atua essa lógica mais ampla de circulação, horizontal, de diferentes práticas midiáticas de encenações musicais.

Será que a circulação de práticas e signos entre as mídias pode ajudar a entender melhor esses números musicais? Se esses números configuravam uma prática e não apenas uma mídia, não seria recomendável investigar o conjunto dessas atividades em certo período? Considero proveitoso fazer caminhar uma pesquisa que investigue como as práticas de palco aparecem dentro e fora dos filmes. Muitas conexões podem ser encontradas se acompanharmos o circuito das músicas do ano e sua veiculação no rádio, na imprensa, nas revistas teatrais e nos repertórios dos cantores. O público vivia essas músicas tanto nas exibições de filmes como no palco anônimo e móvel que são as ruas e o imaginário do carnaval.

O historiador Charles Musser fala da necessidade de uma história integrada de palcos e telas, e critica uma historiografia que coloca o cinema no centro e outras formas culturais na periferia da investigação. Para ele, “o filme pode ser melhor entendido dentro do arcabouço maior, mais rico e mais complexo do entretenimento teatral" (MUSSER, 2004, p. 8). Creio que isso funciona para as chanchadas e seus números musicais.

Nesse sentido, acho que é necessário levar em conta não apenas o teatro popular, mas também as rotinas da sociabilidade carnavalesca, assim como a lógica da indústria fonográfica, as performances no rádio e as práticas multimidiáticas que 
ocorriam na exibição dos filmes, e reconsiderar as afirmações históricas baseadas na especificidade do cinema. A ideia de um intercâmbio de práticas e signos entre mídias pode ajudar a entender essas performances do cinema brasileiro. Parece, nesse sentido, um pouco empobrecedor estudar os números musicais das chanchadas separadamente dos números musicais das revistas, dos do rádio, de Hollywood, e dos números musicais tais como gravados em discos. Nessa perspectiva, sugerimos diminuir a importância dos filmes como fonte exclusiva na explicação das escolhas estilísticas e econômicas desses números musicais, para que possamos buscar um entendimento deles dentro dos filmes, já que, se tomados caso a caso, eles sempre conversam com seu contexto mais amplo.

\section{Referências}

ALTMAN, R. "General introduction: cinema as event". In: (Org.). Sound theory, sound practice. New York: Routledge, 1992. p. 1-14.

ARAÚJO, L. C. “Augusto Annibal quer casar!: teatro popular e Hollywood no cinema silencioso brasileiro”. Alceu, Rio de Janeiro, v. 16, n. 31, p. 62-73, 2015. Disponível em: <https://bit.ly/29Bcyg2>. Acesso em: 28 mai. 2018.

AUGUSTO, S. Este mundo é um pandeiro: a chanchada de Getúlio a JK. São Paulo: Cinemateca Brasileira; Companhia das Letras, 1989.

CIOCCI, S. C. N. Assim era a música da Atlântida: a trilha musical do cinema popular brasileiro no exemplo da Companhia Atlântida Cinematográfica 1942/1962. 2010. Dissertação (Mestrado em Música) - Instituto de Artes, Universidade Estadual de Campinas, Campinas, 2010.

COSTA, F. C. "Chanchada e intermidialidade: alguns comentários sobre Aviso aos navegantes (1950)". Pós, Belo Horizonte, v. 6, n. 12, p. 87-98, 2016. Disponível em: $<$ https://bit.ly/2ISYbnZ>. Acesso em: 28 mai. 2018.

DENNISON, S.; SHAW, L. Popular cinema in Brazil, 1930-2001. Manchester: Manchester University Press, 2004.

FEUER, J. The Hollywood musical. 2. ed. Bloomington: Indiana University Press, 1993.

FRANKIE. "Francisco Carlos vai casar?”. A cena muda, Rio de Janeiro, v. 30, n. 23, p. 10-11, 1951. Disponível em: <https://bit.ly/2L0RDju>. Acesso em: 29 mai. 2018.

FREIRE, R. L. Carnaval, mistério e gângsters: o filme policial no Brasil (1915-1951). 2011. Tese. (Doutorado em Comunicação) - Instituto de Arte e Comunicação Social, Universidade Federal Fluminense, Niterói, 2011. 
"Acabaram-se os otários: compreendendo o primeiro longa-metragem brasileiro sonoro". Rebeca, v. 2, n. 1, p. 104-128, 2013. Disponível em: <https://bit.ly/2LDlBJk>. Acesso em: 28 mai. 2018.

GOMES, T. M. Um espelho no palco: identidades sociais e massificação da cultura no teatro de revista dos anos 1920. Campinas: Editora da Unicamp, 2004.

HEFFNER, H. "Chanchada: gênero nacional". In: NOITES DE CHANCHADA. Almanaque: noites de chanchada: o melhor do cinema popular brasileiro!. Rio de Janeiro: Noites de Chanchada, 2012, p. 6-11.

LENHARO, A. Cantores do rádio: a trajetória de Nora Ney e Jorge Goulart e o meio artístico de seu tempo. Campinas: Editora da Unicamp, 1995.

MUSSER, C. "Towards a history of theatrical culture: imagining an integrated history of stage and screen". In: FULLERTON, J. (Ed.). Screen culture: history and textuality. Eastleigh: John Libbey Eurotext, 2004. p. 3-19.

NAGIB, L. "The politics of impurity". In: NAGIB, L.; JERSLEV, A. (Eds.). Impure cinema: intermedial and intercultural approaches to film. London: I.B. Tauris, 2013. p. 21-39.

NASSER, D. O espetáculo continua. O Cruzeiro, Rio de Janeiro, 2 dez. 1950, p.18-24.

PETHÖ, A. Cinema and intermediality: the passion for the in-between. Newcastle upon Tyne: Cambridge Scholars Publishing, 2011.

RAJEWSKY, I. “Intermidialidade, intertextualidade 'remediação': uma perspectiva literária sobre a intermidialidade”. In: DINIZ, T. (Org.). Intermidialidade e estudos interartes: desafios da arte contemporânea. Belo Horizonte: Editora UFMG, 2012. p. 15-45.

SCHVARZMAN, S. "Cultura popular massiva no Brasil: o lugar do cinema sonoro e sua relação com a música popular”. Ícone, Recife, v. 10, n. 1, p. 77-99, 2008. Disponível em: <https://bit.ly/2GXDPE0>. Acesso em: 28 mai. 2018.

SHAW, L. The chanchada and celluloid visions of Brazilian identity in the Vargas era (1930-45), Journal of Iberian and Latin American Studies, Abingdon-on-Thames, v. 6, n. 1, p. 63-74, 2000. Disponível em: <https://bit.ly/2LF9Sfx>. Acesso em: 28 mai. 2018.

The Brazilian chanchada and Hollywood paradigms (1930-1959). Framework, Detroit, v. 44, n. 1, p. 70-83, 2003. Disponível em: <https://bit.ly/2IT3CDp>. Acesso em: 28 mai. 2018. 
VENEZIANO, N. De pernas pro ar: o teatro de revista em São Paulo. São Paulo: Imprensa Oficial, 2006.

VIEIRA, J. L. Foto de cena e chanchada: a eficácia do "star system” no Brasil. 1977. Dissertação. (Mestrado em Comunicação) - Escola de Comunicação, Universidade Federal do Rio de Janeiro, Rio de Janeiro, 1977.

. "Este é meu, é seu, é nosso: introdução à paródia no cinema brasileiro". Filme Cultura, Rio de Janeiro, n. 41-42, p. 22-29, 1983. Disponível em: $<$ https://bit.ly/2GXKs9x>. Acesso em: 28 mai. 2018.

Hegemony and resistance: parody and carnival in Brazilian Cinema. 1984. Tese. (Doutorado em Cinema Studies) - Tisch School of the Arts, New York University, New York, 1984.

. "A chanchada e o cinema carioca (1930-1955)". In: RAMOS, F. História do cinema brasileiro. São Paulo: Art, 1987. p. 129-187.

. "Cinema e performance". In: XAVIER, I. (Ed.). O cinema no século. Rio de Janeiro: Imago, 1996. p. 337-351.

. "Brazil". In: CREEKMUR, C. K.; MOKDAD, L. (Orgs.). The international film musical. Edinburgh: Edinburgh University Press, 2012. p. 141-154.

\section{Referências audiovisuais}

AVISO aos navegantes. Watson Macedo, Brasil, 1950.

É FOGO na roupa. Watson Macedo, Brasil, 1952.

MUIÉ MACHO sim sinhô. Walter Pinto, Rio de Janeiro, 1950.

\section{Acervos consultados}

Hemeroteca Digital Brasileira, Bilbioteca Nacional.

Fundação Nacional de Artes, Centro de Documentação e Informação, Acervo Walter Pinto. 